https://doi.org/10.52326/jss.utm.2022.5(1).08 UDC 331.5

\title{
WHY WE HAVE UNEMPLOYMENT?
}

\author{
Titu-Marius I. Băjenescu*, ORCID ID: 0000-0002-9371-6766 \\ Swiss Technology Association, Electronics Group Switzerland \\ *Corresponding Author: Titu-Marius I. Băjenescu, tmbajenesco@gmail.com
}

Received: 12.30 .2021

Accepted: 02.06.2022

\begin{abstract}
The article examines the issue of unemployment, which affects the quality of life in all countries, regardless of their level of development. In some countries, many people have to earn a living through long hours of hard and tiring physical work, perhaps even through dangerous and poorly paid work. Until recently, many people in other countries were sure that once they joined a large company or a state-owned enterprise, they would have a job until retirement. Today, however, it seems that there are too few companies or corporations that can provide a convenient and safe job for employees. The causes of the problem, its magnitude for different social categories, the magnitude and some ways of combating the phenomenon of unemployment are elucidated.
\end{abstract}

Keywords: Causes of unemployment, solutions, theories of unemployment, Keynesian unemployment, Great Depression, Keynes, post-war boom, Hartz reforms.

Rezumat. Articolul examinează problema șomajului, care afectează calitatea vieții în toate țările, indiferent de nivelul lor de dezvoltare. În unele țări, mulți oameni trebuie să-și câștige existența prin ore lungi de muncă fizică grea și obositoare, poate chiar prin muncă periculoasă și prost plătită. Până de curând, mulți oameni din alte țări erau siguri că, odată ce se alătură unei companii mari sau unei întreprinderi de stat, vor avea un loc de muncă până la pensie. Astăzi, însă, se pare că există prea puține companii sau corporații care pot oferi un loc de muncă convenabil și sigur pentru angajați. Sunt elucidate cauzele problemei, amploarea acesteia pentru diferite categorii sociale, amploarea și unele modalități de combatere a fenomenului șomajului.

Cuvinte cheie: Cauzele șomajului, soluții, teorii ale șomajului, șomaj keynesian, Marea Depresiune, Keynes, boom postbelic, reforme Hartz.

\section{Causes of the problem}

Some believe we have already reached the limits of prosperity. And if there are fewer employees, there are fewer buyers. In this way, the market produces more than can be consumed. No longer economically viable, large companies, built to achieve the expected increases in production, are closing or being repurposed. Such changes claim victims: the unemployed. In times of economic crisis, the need for labour declines, and jobs lost during the crisis are unlikely to be re-created in good times. Clearly, unemployment has more than one cause [1]. 


\section{An age-old problem}

The "discovery of unemployment" took place in the late $19^{\text {th }}$ and early $20^{\text {th }}$ centuries. In 1895 special government committees were set up to examine and deal with the problem, just as the Select Committee of the House of Commons of Great Britain dealt with "the unhappy plight of those seeking work". Joblessness had become a social blight.

This new worrying situation increased dramatically particularly after the First World War. The conflict, with its frenzied arms production, virtually eliminated unemployment. But in the early 1920s, the Western world faced a series of crises culminating in the Great Depression that began in 1929 and affected all the world's industrial economies. After the Second World War, many countries experienced a new period of economic prosperity, with falling unemployment. But "the current unemployment problem has its origins in the mid1960s," says the Organisation for Economic Cooperation and Development [3]. The labour market took a further hit from the oil crises of the 1970s and the computer information explosion and its subsequent layoffs. Unemployment began its relentless rise, even penetrating the ranks of civil servants and those in positions of responsibility, jobs that were once considered secure.

\section{A social plague}

Both the employed and the unemployed are increasingly protesting about job problems. But while the unemployed are looking for a job, the employed are trying to defend their position, two goals that are not always compatible. Those who have a job are always being called in for overtime. Those without a job remain unemployed. There is a risk that society will split in two on the one hand the over-employed and on the other the marginalised unemployed, who depend almost entirely on the goodwill of the former. In Europe, experts believe, the results of economic prosperity have been felt more by those already working than by those without jobs $[4,5]$.

In addition, unemployment depends on the local economic situation, so in some countries, such as Germany, Italy and Spain, there are huge differences between the needs of one area and another [6]. Are workers willing to learn new jobs or even move to another area or country? This can often be a deciding factor.

\section{Is there a solution in sight?}

Economic recovery does not necessarily imply lower unemployment. As long as growth is insignificant, employers prefer to use the employees they have rather than hire others, which means "prosperity without jobs". And then, usually, the number of people out of work grows faster than the number of new jobs created.

Experts have suggested many recipes for fighting unemployment. Some even contradict each other; it depends on whether those who suggested them were economists, politicians or even workers [7,8]. There are some who propose some tempting offers to companies: increase the need for workers by cutting taxes. Some believe that major state intervention is needed. Others suggest a new division of labour and shorter working hours. This has already been put into practice by some of the big companies, although since the last century in all industrialised countries the working week has been gradually reduced, without this helping to reduce unemployment. Over time, each method proves ineffective, with the costs outweighing the benefits.

Let's be under no illusions: the problem is difficult $[9,10]$. Too difficult to solve? Is there a solution to the unemployment problem? 
Economically, in post-World War II Germany, there was hardly any talk of poverty. Over time, the proportion of low wages increased and poverty and precariousness grew (Figures 1, 2, 3).

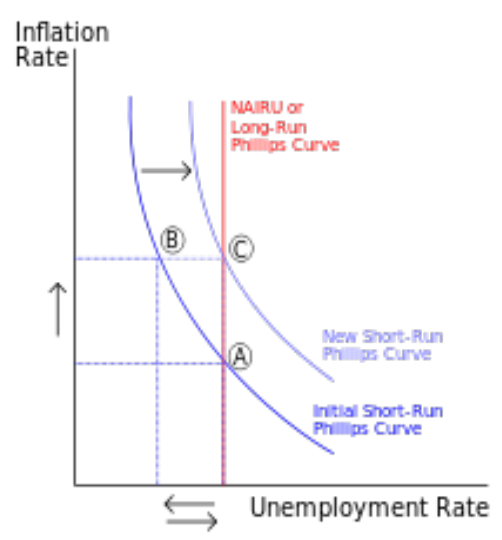

Figure 1. Short-Run Phillips Curve before and after expansionary policy, with Long-Run Philips Curve (NAIRU). Note, however, that the unemployment rate is an inaccurate predictor of inflation in the long term.

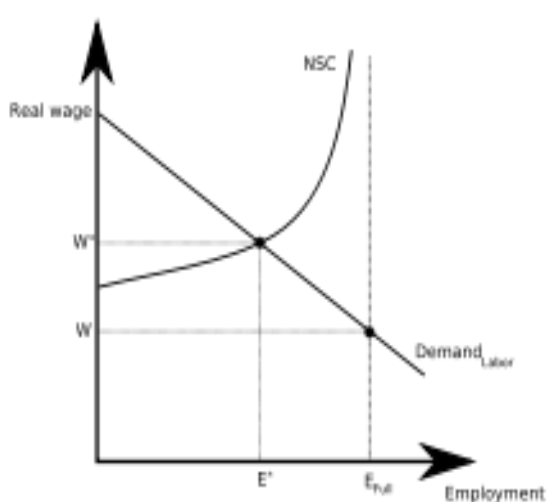

Figure 2. The Shapiro-Stiglitz model of efficiency wages, workers are paid at a level that dissuades shirking. That prevents wages from dropping to market clearing levels.

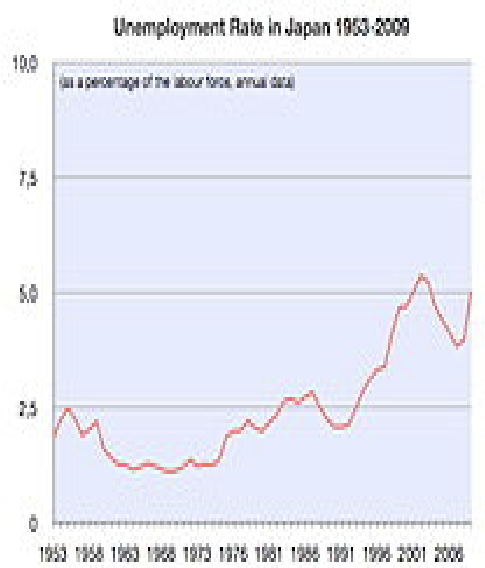

Figure 3. Unemployment rate in Japan (1963-2009).

\section{The exception of the post-war boom}

Since the economic miracle, Germany has been considered one of the countries where poverty played only a marginal role [11]. In view of the euphoria about "the new full employment", however, it is easy to overlook how great social inequality has become, how strongly the low-wage sector has grown and precariousness has increased. Beneath the surface of a seemingly stable society, the pillars of social integration have been eroding for a long time, crashes and descents are multiplying [12].

Another aspect relevant to the assessment of the generation and manifestation of unemployment refers to the fact that the release of labour for reasons of restructuring in various branches and economic units has increased, while the demand for jobs has stagnated due to economic uncertainty and the slow restructuring of the economy. The improvement of this situation requires a series of major actions such as: the firm implementation of a scientific, realistic and coherent strategy for the development of the national economy and its branches; the implementation of privatization, restructuring and modernization of economic units on the basis of economic and social efficiency; the improvement of professional training, in accordance with the requirements of the retraining of the workforce; the development of managerial capacity from the microeconomic to the macroeconomic level $[13,14]$. From an examination of the main aspects of the genesis of unemployment, several significant features can be drawn. Such features can be systematized as follows: the significant increase in the number of unemployed throughout the transition to a competitive market economy. 
Full employment in the labour market, with the gap between labour demand and labour supply in favour of the latter. There are also subjective causes, which have to do with the reluctant behaviour of economic agents to hire young people, either because of their lack of experience or because they do not fit into the work discipline. Unemployment among young people also occurs as a result of the tendency to seek higher-paid jobs, which delays their active integration. Technical progress - in the short term - it generates unemployment, to a greater or lesser extent, depending on the financial capacity of countries to assimilate new scientific research. In the long term, it generates new needs, which are met by products resulting from new job-creating activities $[15,16]$. Economic crisis - characterised by declines or stagnation in economic activity - increases the number of unemployed, their integration is at a low level. The absorption of a larger number of unemployed depends on the real possibilities of each country to stimulate economic agents to increase capital investments.

Changes in the structure of economic branches and sectors - under the impact of the diversification of the demand for goods, of the energy crisis - lead inevitably for a long period to a reduction in the demand for labour [16]. The immigration of part of the working population for employment in different countries will increase the supply of labour in those countries. Emigration has the opposite effect, decreasing the labour supply in the area of origin [17, 18]. Unfavourable international economic and political environment - due to fluctuations in the pace of economic growth - armed conflicts, the promotion of embargo policies negatively influence economic relations concerning import-export, deteriorating economic activities in the countries of the area and contributing to the increase in unemployment [19]. An important cause underlying the downward trend in unemployment is, on the one hand, the emigration of a large part of the labour force and, on the other hand, the return of a large number of people who have exceeded the period of unemployment benefit to register with the Employment Agency.

\section{Measures to combat unemployment}

Active policy measures to reduce unemployment are [20 - 23]:

- New employees are given a probationary period, during which they receive lower pay, flexible working hours, easier termination of employment contracts and flexible wage rates according to the economic situation;

- The unemployed are trained and coached in how to look for a job;

- Those who live in the country and have a foreign nationality are included in the process;

- The level of qualifications and training in schools is raised.

The removal of all barriers on the labour market (specific labour law rules) would eliminate all forms of involuntary unemployment, increase competition between employees for the best jobs (higher wages and better working conditions), increase competition between employers for the best employees, with the effects of increasing labour productivity, reducing red tape, increasing people's real incomes across the board, and stimulating people's desire for education. The unemployed are those in the available labour force who want to work and are looking for paid work because they do not currently have such a job. The unemployed include people who have lost their jobs and new job seekers who cannot find work. Not every person who is not working can be considered unemployed (for example military personnel on leave or housewives). Unemployed is - according to the International Labour Office (ILO), an organisation of the United Nations system - anyone who is 15 years of age, able-bodied 
and not working, looking for work and can be employed in part or in full in paid or unpaid work.

\section{The problem of measuring unemployment}

Measuring unemployment is a problem of estimating its proportion, structure, interasity and duration. In all countries with a competitive market economy, specialised institutions operate and specific methods are applied to record unemployment, about which information is systematically collected: level, increase or proportion at a given time; intensity or severity of occurrence; average duration; structure or composition.

\section{Unemployment and capitalism}

As modern economics has shown, it is quite possible to create full employment if the state takes the appropriate economic policy measures. Unemployment arises from a lack of purchasing power, its ultimate root being the fact that capitalism is not inclined to give the workers a larger share of the national income so as to ensure the consumption of the goods produced. This can be remedied if the state injects additional purchasing power into the masses in some form. For example, by reducing mass taxes, by subsidizing essential goods, by providing child allowances from public funds, by providing new housing at low interest rates, etc. The financing of additional state expenditure (through bonds or taxes on profits) is a technical question that can be solved without difficulty, and the increase in state debt does not pose an insurmountable problem either. Modern economics has shown exactly how to achieve permanent and stable national employment, yet why is it not done? [15]

Capitalism suffers from the fact that it does not want to give the workers enough purchasing power; the policy of full employment means that the state provides the workers with additional purchasing power so that it can sell the otherwise unsalable production. It thus amounts to capitalism outwitting itself, so to speak, and having the state transmit to the worker the purchasing power that the entrepreneurs themselves do not want to grant him directly. Can the self-surveillance succeed? There are serious political reasons against this. If the capitalists were to assign to the state the task of consistently pursuing a policy of full employment, they would thereby strengthen the influence and power of the state in a way that seems to them unwelcome and dangerous $[16,17]$. Capitalism generally seeks to keep the state weak enough to prevent any danger that it could become independent of the owners of capital. This is the basis of every parliamentary regime and of democratic capitalism.

If the state were now given the task of ensuring full employment and if it were also enabled in terms of personnel and organisation to fulfil this task, then its influence would increase considerably. It would be a much stronger state, which would achieve something, which would realise a purposeful concept of economic policy, instead of merely taking over the orders of special interests. the consciousness of its performance would make it less dependent on the owners of capital. The second main reason for the aversion to full employment is unabashedly put forward by the representatives of capitalism itself. Full employment would free the worker from the constant threat of unemployment and the entrepreneurs would thus lose the decisive means of disciplining the workers.

That is a bankrupt view of life, but that is how they are. We can no longer be surprised that in the Western countries (England, America) there has been a storm of protest in recent years against the new-fangled ideas of full employment $[18,19]$. It is extremely important for progressive socialists to know, that the owners of capital will never grant the demand.... although it is within their power to do so. But we must not stop raising this demand loudly 
in concrete form, because only from this constant demonstration of the evil will of capital can come for us the moral force to create change.

\section{Hartz reforms; consequences and criticism}

The Hartz reforms are the labour market reforms that took place in Germany between 2003 and 2005 under the mandate of Chancellor Gerhard Schröder (SPD) [19]. The inspiratory for these reforms, Peter Hartz, was the personnel director at Volkswagen, where he negotiated agreements on flexible working hours. The aim is to strengthen the fight against voluntary unemployment and to improve the return to work of benefit recipients. These controversial reforms, officially, aim to adapt German (labour, tax) law to the new economic situation in the service sector.

Intended consequences: (a) shorter vacancy periods; (b) rising employment rate; (c) promotion of reintegration into the labour market; e.g. through shorter placement times (d) increased flexibility; (e) reduction of labour costs; ( $f$ ) impairment of status security; $(g)$ social security systems come under pressure; (h) displacement of employment subject to social security employment; (i) reduction of active labour market policy; (j) reduction of further training measures; $(k)$ concept of demanding and promoting is not target group oriented.

Non-intended consequences. (1) Impairment of status security; (2) social systems come under pressure; (3) displacement of employment subject to social security employment; (4) reduction of active labour market policy; (5) reduction of further training measures; (6) concept of demanding and promoting is not target group oriented.

\section{Conclusion}

From Keynesian theory to what will be disseminated as Keynesianism, the difference is not negligible. The Cambrian current, made up in part of the members of the "circus", who inspired Keynes, criticised him, forced him to clarify his thinking on a number of points and who would continue it after his death. Keynesianism reduced to a mechanics of global quantities was then disseminated. The temporal dimension and the role of uncertainty are evaded, as well as anticipations and part of the monetary phenomena. At the same time, economic policies were largely inspired by Keynesian precepts, albeit with varying degrees of distortion. Among the recent epigones we should mention the current that developed during the 1970s in France with the "neo-Keynesians" preoccupied with the microeconomic foundations of macroeconomics, known for their developments on the "theory of imbalances". Finally, the so-called "post-Keynesian" current, is essentially American. This line of research focuses on the problem of forecasts that can influence the volume of employment, a crucial problem today as it was in Keynes' time. The school of regulation can be linked to this current.

For monetarists, inflation is always a monetary phenomenon [25]. Therefore, in the event of a cyclical problem, the State intervenes by means of a budgetary policy that can lead to a deficit; making up for this deficit by creating money has the effect of triggering inflationary pressure. But in addition, this policy changes real income and the exchange rate, so that - if an increase in the money supply temporarily reduces unemployment - it permanently increases the inflation rate. Conversely, an anti-inflationary policy will be sanctioned by an increase in the unemployment rate.

Unemployment is a major phenomenon in most industrialised countries, it is a daily reality for many people today, it is also the object of debates among economists [26]. There is no problem without a solution, but there are no miracle solutions or cures immediate or without considerable effort.

Unemployment is a flaw in the capitalist system. 


\section{References}

1. Freyssinet J. [1986], Chômage, jusqu'où ?» Études, février.

2. Ferry J. Plein emploi, rapport du Conseil d'analyse économique, no 30.

3. Berthet T., Cuntigh P., Guitton C. et Mazel O. [2002], «La territorialisation progressive des politiques de l'emploi», Premières Synthèses, no 24-2, DARES.

4. Laroque G., and Salanié B. [2000], «Une décomposition du non-emploi en France», Économie \& Statistique, no 331.

5. Simonin B. [2003], «L'usage des emplois aidés par les employeurs du secteur non marchand : logiques sociales, logiques de gestion», Premières Synthèses, no 06-2, DARES.

6. Snower D. J. [1994], «Converting unemployment benefits into employment subsidies», American Economic Review (Nashville), vol. 84, no 2, may, pp. 65-70.

7. Conseil national de l'évaluation - Commissariat général du Plan [2002], Rapport de l'instance d'évaluation des mesures d'aide aux emplois du secteur non marchand présidée par Yves Robineau, février, La Documentation française.

8. Taylor J. B. [1993]. «Discretion versus policy rules in practice», Carnegie-Rochester Conference Series in Public Policy, 39, 195-214.

9. McDonald I. M., and Solow R. M., [1981], «Wage bargaining and employment», American Economic Review, 71, pp. 896 - 908.

10. Lindbeck ASSAR and Dennis J. Snower [1988], «The insider-outsider theory of employment and unemployment».

11. Calmfors Lars, and John Driffill [1988], «Bargaining Structure, Corporatism and Macroeconomic Performance», Economic Policy, Vol. 3, No. 6 (Apr., 1988), pp. 13 - 61.

12. Bouygard F. and Gelot D. (éds) [2002], «Nouveaux services-emplois jeunes: Regard à mi-parcours», Cahier Travail et emploi, La Documentation française.

13. Crépon B. and Desplatz R. [2002], «Une nouvelle évaluation des allégements de charges sociales sur les bas salaires», Économie \& Statistique, no 348.

14. Keynes J. M., and Skidelsky Robert [2015], «The essential Keynes» Penguin Classics.

15. Steindl J. [1950] «Kapitalismus ohne Arbeitslosigkeit» Wirtschaft und Gesellschaft, 45 Jahrgang (2019) Heft 2, pp. $288-290$.

16. Collected Works of Michal Kalecki, [1990], Volume 1: Capitalism: Business Cycles and Full Employment, Clarendon Press.

17. Collected Works of Michal Kalecki, [1991], Volume II: Capitalism: Economic Dynamics, OUP Oxford.

18. Collected Works of Michal Kalecki, [1993], Volume III: Socialism: Functioning and Long-Run Planning, OUP, Oxford.

19. Keynes J. M., and Skidelsky, Robert, [2015], «The essential Keynes» Penguin Classics.

20. Sanchez R. [2002], «Formation et insertion des jeunes: les entrées en contrats d'apprentissage et de qualification en 2000», Premières Synthèses, no 07-2, DARES.

21. Stiglitz J. E. and Greenwald B. [2003], «Towards a New Paradigm in Monetary Economics », Raffaele Mattioli Lectures, Cambridge University Press, Cambridge, UK.

22. Collected Works of Michal Kalecki, [1993], Volume IV: Socialism: Economic Growth and Efficiency of Investment, Clarendon Press.

23. Collected Works of Michal Kalecki, [1993], Volume V, Developing Economies, Clarendon Press.

24. Collected Works of Michal Kalecki, [1996], Volume VI: Studies in Applied Economics 1927-1941, Clarendon Press, 1996.

25. Collected Works of Michal Kalecki, [1997], Volume VII: Studies in Applied Economics 1940-1967; Miscellanea, Clarendon Press, 1997.

26. Kalecki M. [1943]. «Political Aspects of Full Employment». Monthly Review. The Political Quarterly. Retrieved 2020-05-02. 